\title{
Methane Production From Animal by-Products and Wastes
}

\author{
Daoud Elzubair Ahmed ${ }^{1 *}$, Intisar Yousif Turki ${ }^{2}$ \\ College of Animal Production Science and Technology, Sudan University of Science and Technology, \\ Khartoum - Sudan ${ }^{1}$. \\ College of Animal Production Science and Technology, Sudan University of Science and Technology, \\ Khartoum - Sudan ${ }^{2}$.
}

Rec. 17 Dec, 2010; Accpt. 28 Janu. 2011

\begin{abstract}
This study was carried out in the laboratory of nutrition, College of veterinary medicine and animal production. The study was continued for 30 days. The results obtained in this study were very satisfactory. The mixed treatment $(50 \%$ poultry droppings $+50 \%$ hides $)$ recorded the highest amount of methane $\left(1308 \mathrm{~cm}^{3}\right)$, followed by hide by- products $\left(570 \mathrm{~cm}^{3}\right)$ and poultry droppings $\left(250 \mathrm{~cm}^{3}\right)$ respectively. The nitrogen and crude protein contents of the slurry (residue of the digestion) were recorded. The highest crude protein content was in mixed slurry $(8.5 \%)$, poultry droppings $(6.88 \%)$ and hide by - products $(5.88 \%)$ respectively. The physical measured properties were normal in color, smell and neutral $\mathrm{PH}$. The carbon dioxide emitted (turbidity) was highest in the mixed treatment, followed by hide by - product and poultry droppings respectively. The methane production through simple methods can be implemented in the sub-urban and rural areas without complications and can contribute in the wellbeing of the rural people.
\end{abstract}

Keywords: - Methane, Fermentation, Biomass

\section{Introduction}

Methane fermentation has been used since 1900 for treating excess sludge discharged from sewage treatment plants. This technique has been developed to treat waste water, such as those derived from alcohol distillation, antibiotic production and baker's yeast manufacture (Leisinger, 1993). Methane is a renewable energy source that can be beneficial especially in rural areas as a source of power, lighting and cooking, instead of using cattle dung as in India and/or wood as in other poor countries (Siagh, 2000). The anaerobic digestion is a microbial process that occurs in the abscence of oxygen. In this process, a community of microbial species break-down both complex and simple organic materials, ultimately producing methane and carbon dioxide. Anaerobic digestion is slower than aerobic waste treatment process, requiring retention times of 10 to 30 days for mesophilic $\left(95^{\circ} \mathrm{F}\right)$ digestion (Cady et al., 2004).
As a result of greatly improved methanogen isolation techniques developed by (Hungate, 1969). more than 40 strains of pure methanogens have been isolated. Methanogens are divided into two groups, $\mathrm{H}_{2} / \mathrm{Co}_{2}$ and acetate consumers. Since a large quantity of acetate is produced in the natural environment, methane sources and methanothrix play an important role in completion of anaerobic digestion and accumulating hydrogen $\left(\mathrm{H}_{2}\right)$, which inhibits acetogens and methanogens. Hydrogen consuming methanogens are considered important in maintaining low level of atmospheric hydrogen (Thompson et al., 1976).

Agriculture is one of the major sources of methane, nitrogen and phosphorus (P) pollution.

\footnotetext{
* Corresponding author:

Dr. Daoud Elzubair Ahmed

$\checkmark$ daoud.alzubair@yahoo.com
} 
Methane emissions are significant contributors to the green house effect, second to the carbon dioxide importance (Ahmed and Hamid, 2009).

Emissions from ruminants are estimated at $74 \mathrm{Tg}$ of methane per year and accounts between $10-15 \%$ of total methane emissions (Kebreab et al., 2001). They added that methane produced naturally in ruminants during normal digestion in the rumen, is wastefully exhaled into the air representing loss of $4-15 \%$ of animal's feed energy. (Kebreab et al., 2002). reported that, 6-8\% of gross energy lost in methane. Similarly Moss et al., (2001) reported that, in high digestible rations $(>70 \%), 4-6 \%$ of the total digestible energy converted in to methane. They added, rumen fermentation resulted in $87 \%$ and the gut fermentation contributes about $13 \%$ of the total methane produced. (A.O.A.D. 1992). reported that, in the cow dung fermentation the biogas produced composed of $55-65 \%$ methane and $30-35 \%$ carbon dioxide and heating value of methane is 600 B.T.U. per cubic feet with blue flame, while the natural gas consist of $80 \%$ methane that yields 1000 B.T.U. They added that the cow dung slurry is composed of 1.8$2.4 \%$ nitrogen and $1.0-1.2 \%$ phosphorus $\left(\mathrm{P}_{2} \mathrm{O}_{3}\right)$.

(Ahmed and Hamid, 2009). reported high nitrogen content in the poultry droppings as $0.8-1.5 \%$ which enables microbes in digestion and hence produce more biogas. (Lanyasuna et al., 2006). reported nitrogen content in the slurry as $1.0-$ $1.2 \%$.

In the recent years, the conversion of biomass to methane for use as an energy source has excited interest throughout the world. The biogas digestion was introduced into the developing countries as a low cost alternative and renewable energy source to particularly alleviate the problem of acute energy shortage for households and to lessen its emission into the environment and contributes in global warming (Ahmed and Hamid, 2009).

The objective of this study is:
$-1 \backslash$ To spread the technology of biogas production as a renewable, clean and safe energy source.

$2 \backslash$ To convert animal by-products into useful source of energy especially in the rural areas.

$3 \backslash$ To introduce the biogas technology to the households in the rural areas and hence safe the time and effort lost in collecting wood.

4\ Biogas production prevents the environmental pollution produced by dumping the by-products and prevents the flies and bad odor arise from.

\section{Materials and Methods}

Locality: This experiment was conducted in the nutrition laboratory, department of Animal Production, college of Veterinary Medicine and Animal Production, Sudan University of Science and Technology, from May - June (2009).

\section{Samples preparation:}

Limed fleshing were collected from Africa Tannery-Khartoum North, they were washed with Tape water, delimed with diluted hydrochloric acid to $\mathrm{pH} 7 / 7.5(\mathrm{pH}$ was monitored by the phenolphthalein indicator and the lyphan $\mathrm{pH}$ papers). The poultry dropping were collected from the college poultry farm.

Methods: Three treatments were carried out as follows:-

(I) $5 \mathrm{~kg}$ cattle hide fleshing +5 liter of water. (II) $5 \mathrm{~kg}$ poultry droppings +5 liter of water.

(III) $2.5 \mathrm{~kg}$ cattle hide fleshing $+2.5 \mathrm{~kg}$ poultry dropping +5 liter of water, (I+II).

Each trial was subjected to anaerobic digestion in a 10 liters volume

Plastic bottle, which was connected to a plastic container containing $2 \%$ lime solution to absorb $\mathrm{Co}_{2}$ while the other trace gases absorbed in $\mathrm{H}_{2} \mathrm{O}$. The system was connected to an inverted measuring cylinder containing water, in such away to measure the volume of the generated methane gas displacing the water. The experiment continued for 30days. The volume of the methane gas accumulated during this period was measured for each treatment (in $\mathrm{cm}^{3}$ ). Samples were taken from digestion residue 
(slurry) for determination of nitrogen content. Some physical parameters were observed and measured e.g. color of the flame, smell and $\mathrm{pH}$ of the methane gas. The observations were recorded. The collected data were statistically analyzed by T-test to the significance of 5\%.

\section{Results}

The results obtained in this study were presented in (table I), (table II), and (table III).

(Table I), showed the volume of harvested methane gas (in $\mathrm{cm}^{3}$ ), the daily average emission and the emission rates for the three treatments were included. The mixed treatment $(50 \%$ poultry dropping $+50 \%$ hides) recorded the highest harvested volume of methane $\left(1308 \mathrm{~cm}^{3}\right)$ followed by hide by-products $\left(570 \mathrm{~cm}^{3}\right)$ and poultry droppings $\left(250 \mathrm{~cm}^{3}\right)$ respectively. Similarly the daily average emissions were $43.6 \mathrm{~cm}^{3}$, $19.0 \mathrm{~cm}^{3}$ and $8.3 \mathrm{~cm}^{3}$ for the mixed, hides and poultry droppings respectively. The emission rates for the three treatments were rapid, moderate and slow for the mixed, hides and poultry droppings respectively.

In (table II) the nitrogen and crude protein contents of the slurry of the three byproducts were showed. The highest protein content was in the mixed slurry $(8.50 \%)$ followed by poultry droppings $(6.88 \%)$ and hides by-product $(5.88 \%)$ respectively.

(Table III). showed some physical properties of the methane gas emitted from the three by-products. The observed color of the flame for the three treatments was blue without any smoke. Similarly the $\mathrm{pH}$ test for the gas emitted from three treatments was neutral (7.0). The smell of the emitted methane gas for the three treatments was normal smell. The turbidity of the lime $(\mathrm{CaCo} 3)$ was (high) in mixed treatment $(50 \%$ hides $+50 \%$ poultry droppings), followed by the hides (moderate) and lastly of poultry droppings (light turbid).

\begin{tabular}{|l|c|c|c|c|}
\hline \multicolumn{1}{|c|}{ Treatment } & $\begin{array}{c}\text { Amount } \\
\mathbf{( k g )}\end{array}$ & $\begin{array}{c}\text { Volume of methane } \\
\mathbf{c m}^{\mathbf{3}} \text { production }\end{array}$ & $\begin{array}{c}\text { Average daily } \\
\mathbf{\text { emission }} \mathbf{c m}^{\mathbf{3}}\end{array}$ & Rate of emission \\
\hline Mixed (50\% hide $+50 \%$ & 10 & 1308 & 43.6 & Rapid \\
droppings) & 10 & 250 & 8.3 & Slow \\
Hides & 10 & 570 & 19.0 & Moderate \\
Poultry droppings & & & \\
\hline
\end{tabular}

Table (I): The volume of methane gas and average daily emission

\begin{tabular}{|l|c|c|}
\hline \multicolumn{1}{|c|}{ By-product } & Nitrogen \% & Crude protein \% \\
\hline Mixed (50\% hide + 50\% droppings & 1.36 & 8.50 \\
Hide & 0.94 & 5.88 \\
Poultry droppings & 1.01 & 6.30 \\
\hline
\end{tabular}

Table (II): The nitrogen and crude protein content of the slurry for the three by-products

Note

C.P. $=\mathrm{N}_{2} \times 6.25$

\begin{tabular}{|l|c|c|c|c|}
\hline \multicolumn{1}{|c|}{ By-product } & Color of flame & pH & Smell & Turbidity \\
\hline Mixed (50\% hide $+50 \%$ & Blue & 7.0 & Normal & High \\
droppings) & & & & \\
Hide & Blue & 7.0 & Normal & Moderate \\
Poultry droppings & Blue & 7.0 & Normal & Light turbid \\
\hline
\end{tabular}

Table (III): Some physical properties of methane gas (observations) 


\section{Discussion}

The results of this study revealed that the mixed treatment $(50 \%$ hide $+50 \%$ poultry droppings) gave the highest volume of harvested methane gas $\left(1308 \mathrm{~cm}^{3}\right)$, followed by hides $\left(570 \mathrm{~cm}^{3}\right)$ and then poultry droppings $\left(250 \mathrm{~cm}^{3}\right)$. This may be due to the favorable condition created for the anaerobic bacteria (optimum condition for anaerobic digestion). These results are confirmed by the rate of methane emissions. It was high in the mixed treatment, followed by hides (moderate) and then, poultry droppings (slow) respectively. Similar findings were reported by (Kabreab et al., 2001; Kabreab et al. 2002; Leisinger 1993; and Siagh, 2000). The digestion period in this study was 30days. Similar period was suggested by (Arab Organization for Agriculture Development, 1992; and Cady et al. 2004). The turbidity of the lime water $\left(\mathrm{CaCO}_{3}\right)$ solution was higher in the mixed treatment, followed by hides and poultry droppings respectively. This result confirmed that, the emission of carbon dioxide was higher in the mixed treatment, then hides and poultry dropping respectively.

The nitrogen and crude protein content in the study were $(1.36,8.50),(1.01,6.30)$ and $(0.94,5.88)$ for the mixed by-products, poultry droppings and hides slurry respectively. The lower nitrogen in hide's slurry $(0.94,5.88)$ may be due to lower quality of hide's crude protein (lower lysine and treptophan contents) as reported by (Lanyasuna et al., 2006). The high content of nitrogen in the poultry slurry $(1.01,6.30)$ is similar to that reported by (Ahmed and Hamid, 2009) as 0.8-1.5 and (Lanyasuna et $a l ., 2006)$. as ranging between $1.0-1.2 \%$.

The physical parameters measured or observed for the methane emitted from the three treatments were, the color of the flame which was blue without any smoke, the $\mathrm{pH}$ was neutral (7.0) and the smell was normal in the three treatments. These findings were coincided with those reported by (Arab Organization for Agriculture Development, 1992). as color of the flame is blue without any smoke, the $\mathrm{pH}$ is ranging between (7.08.0) and the smell is normal and did not attracts insects. The neutral $\mathrm{pH}$ in this study is confirmed by the report of (Hungate, 1969). that the methanogens (hydrogen consumers) play an important role in maintaining low level of atmospheric hydrogen. The physical parameters of this study were similar those reported by (Moss et al., 2001; and Thompson et al., 1976).

The results of this study revealed clearly that this simple operation can be implemented easily in sub-urban and rural areas for methane production which can be used for cooking (instead of woods and dungs) and for lighting and hence contribute in preventing environmental pollution, desertification and global warming.

\section{References}

A. O. A. D. (1992). Biogas production and usage. Egypt 1992.

Ahmed, D. E. and Hamid, E. (2009). Methane production and global warming. Journal of Arab Agricultural Investment Authority (2009) under publication.

Cady, R. Engter., Ellen, R. Jordan and Marshal, J. (2004). Economics and environmental impact of biogas production as manure management strategy. Texas, U. S. A.

Hungate, R. E. (1969). Aroll tube methods for cultivation of strict an aerobes Methods in microbiology (Norris, I.B and Ribbons, D.W. eds). Pp. 116-132. Academic press. New York.

Kebreab, E. Cromptom., L.A. Mills, J. A. N. and France, J. (2001). Phosphorus pollution by dairy cow and its mitigation by dietary manipulation. Proceedings. British society Animal science 138.

Kebreab, E., France, J., Mills, Z.A.N.; Allison, R. and Djikstra, J. (2002). A dynamic model of $\mathrm{N}_{2}$ metabolism in lactating dairy cow and an assessment of impact of $\mathrm{N}_{2}$ excretion on the environment. J. of Animal Science. 80: 248 - 259 .

Lanyasuna, T.P., Wang H. Rong, S.A. Abulrazak, P.K. Kaburu, J.O. Makori, T.A. Onyango and Mwang. D.M. (2006). Factors limiting use of poultry manure as protein supplement for dairy cattle on small holder farms in Kenya. International journal of poultry science 5(1): 75-80.

Leisinger, T. (1993). In genetics and molecular biology of anaerobic bacteria. Ed. Sebald, M. 1-12 (1993). New York. 
Moss, R., Jouany, J.P. and Newbold, J. (2001). Methane produced by ruminants, its contribution to global warming. Annals of Zootech: 49: 231-53.

Ram B.S. (2000). Biogas production in India. Gobar Gas Research Station. India.

Thompson, L.A., Gats, D.M., Ingledew, W.M. and Jones, G.A. (1976). Use of Hungate anaerobic techniques (1969) in the isolation of phloroglucinol-negative mutant of corpococcus species. Applied Environmental Microbiology (1976) Vol. 31 No. 1.

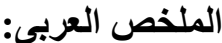

أجريت هذه الدراسة في كلية الطب البيطري والإنتاج الحيواني - جامعة السودان للعلوم والتكنولوجيا (حلة كوكوالخرطوم بحري ـ السودان). إستمرت الدراسة لنحو ثناثون بوماً، أهمية هذه الدراسة تنبع من الإهنمام العالمي المتزايد بالغاز الحيوي وتأثيره علي الإحتباس الحراري ولأن هذا الغاز يعتبر رخيصاً ومن الطاقات المتجددة المستخدمة في الأرياف، النتائج المتحصلة من هذه الدراسة كانت إيجابية حيث سجل خليط زرق الدواجن ( •0\%) ومخلفات الجلود

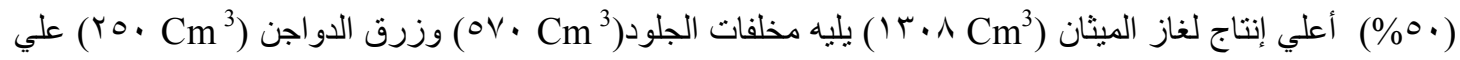
التوالي. محتوي النيتروجين والبروتين الخام في الراسب (مخلفات التخمير اللاهوائي) سجل أعلي نسبة (^,ه) في

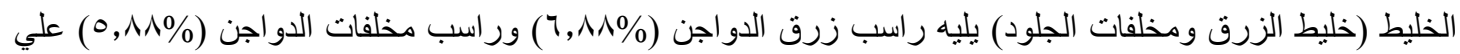
التو الي، بعض القياسات الفيزيائية والكيميائية لغاز الميثان كانت عادية في اللون والرائحة أما الأس الأيوني فكان متعادلاً

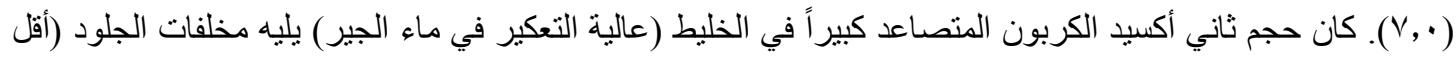
تعكير) ثم زرق الدواجن (تعكير خفيف لماء الجير) علي التوالي، خلصت الدراسة إلي أن إنتاج الغاز الحيوي بالطريقة البسيطة مفيدة في القري و الأرياف ويساهم في ترقية ورفاهية إنسان الريف بمده بمصدر طاقة رخيصة ومتجددة. 